\section{La cultura Yoruba en América}

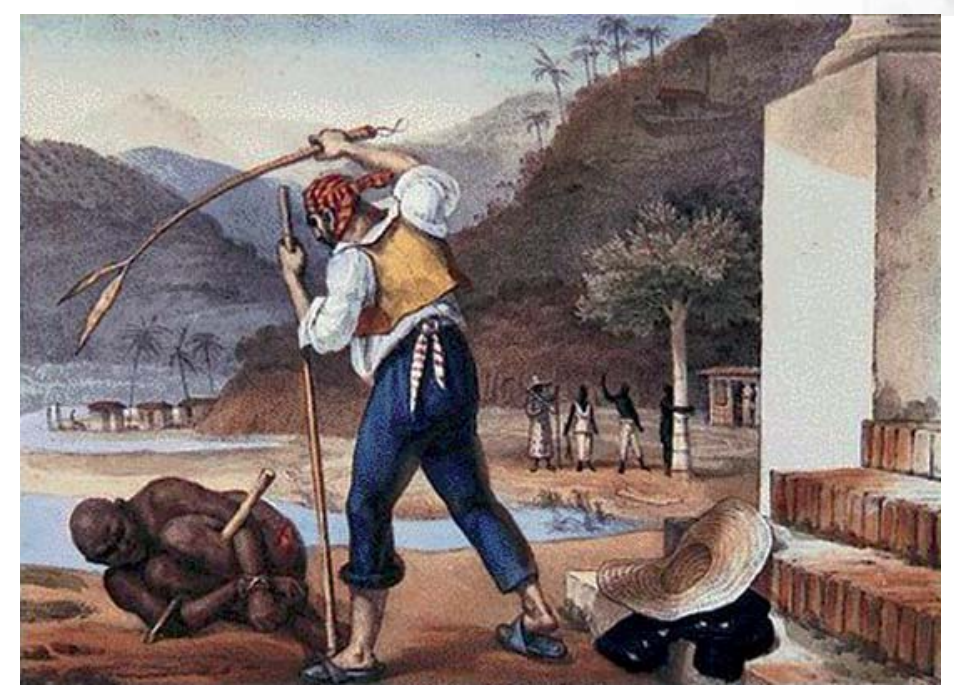

Esclavitud en Brazil. Jean Baptiste Debret (1768-1848).

La diáspora de numerosas etnias africanas durante los cuatrocientos años que duró el tráfico de esclavos es posiblemente la tragedia más grande de la humanidad.

La conquista europea despobló el continente, desató la barbarie, creó fronteras artificiales y sumió al continente africano, cuna de la humanidad, en el horror en que aún se debate. Se estima que más de veinte millones de africanos fueron capturados y vendidos, de los cuales alrededor de diez millones murieron en cautiverio o durante el transporte.

A pesar de los sufrimientos, los integrantes de estas etnias lograron conservar sus raíces, su cultura, su arte, su lengua, su religión y sus dioses al fundir sus ritos y leyendas, como en un crisol, con las poderosas religiones y culturas existentes donde arribaron.

Los Yoruba provenían de un reino ubicado en lo que hoy es Nigeria, y su destino como esclavos es tardío en relación a otras etnias ya que se remonta a finales del siglo 18 y principios del 19; sin embargo, su cultura, su religión y su lengua se convirtieron en dominantes respecto a la de los otros esclavos en gran parte de Iberoamérica, especialmente en Cuba y Brasil, donde desarrollaron un profundo sincretismo religioso con la religión católica.

Al igual que otras culturas, reconocían un ser supremo y creador llamado Olodumaré, y un panteón de dioses intermedios llamados Orichas, de rasgos humanos, los que fueron identificados con los santos católicos por los esclavos.

Jorge Amado, bahiano y escritor, escribió 27 leyendas para los Orichas y sus santos correspondientes, los que fueron delicadamente esculpidos en madera por el artista Héctor Bernabó Carybé y se exponen en el Museo Afro-Brasileño de Bahía.

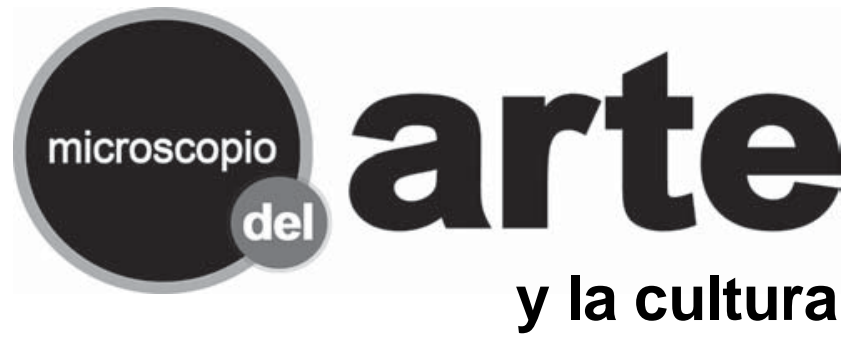

Pierre Verger, quién viajó por las costas de Africa, en tierras yorubas, recopiló el siguiente relato: “Un babalao me contó: Antiguamente los Orichas eran hombres; hombres que se volvieron Orichas gracias a sus poderes, hombres que se volvieron Orichas por su sabiduría. Eran respetados por su fortaleza, eran respetados por sus virtudes. Los hombres eran numerosos sobre la tierra; antiguamente, como hoy, muchos no eran ni valientes ni sabios; su recuerdo no se perpetuó; fueron completamente olvidados, no se volvieron Orichas. En cada pueblo se estableció un culto sobre el recuerdo de un ancestro de prestigio, y sus leyendas fueros transmitidas de generación en generación, para rendirles homenaje."

Nunca sabremos cuántos santos africanos, cuántos Orichas valientes y sabios fueron vendidos como esclavos o murieron en los barcos negreros que surcaban los mares en la oscura época de la esclavitud.

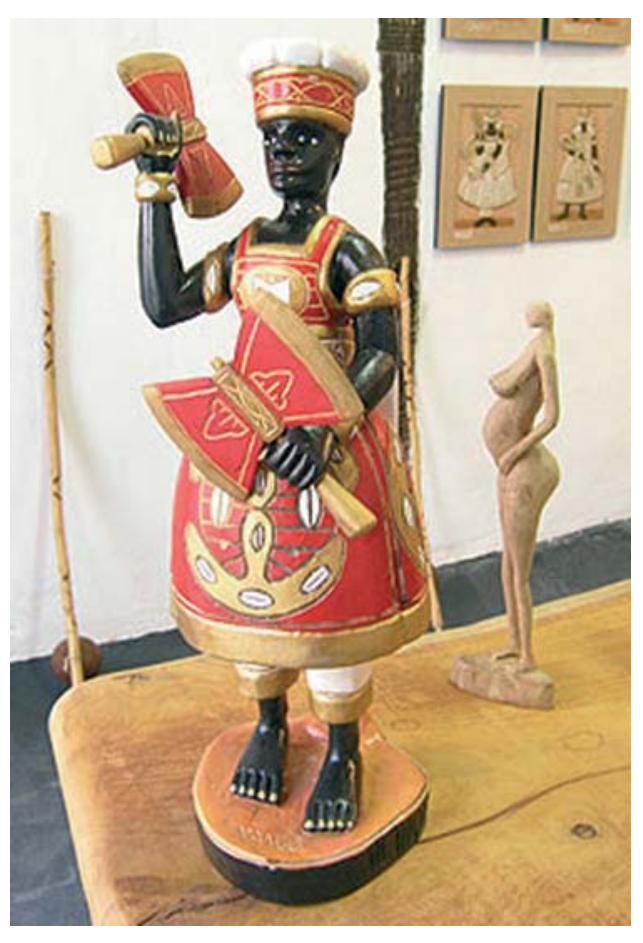

Imagen de Xangó.

\section{Referencias}

1.- Amado J. Bahía de Todos los Santos. 9ª edición. 1999. Losada editores, Buenos Aires.

2.- Pierre Fatumbi Verger, Carybé, Lendas Africanas dos Orixas. 4a edición. 1997. Corrupio editores, Salvador. Fatumbi Verger, Carybé, Lendas Africanas dos Orixas. $4^{\text {a }}$ edición. 1997. Corrupio editores, Salvador.

Colaboración de: Ernesto Payá G. 